\title{
PERAN STRATEGIS TOP MANAGEMENT TIM (TMT) DALAM ORGANISASI: SEBUAH TELAAH KRITIS DAN EVALUASI TERHADAP STUDI DALAM KONTEKS ASIA
}

\author{
Fadhliah M. Alhadar \\ Universitas Khairun Ternate \\ e-mail : fadhliah.alhadar@gmail.com
}

\begin{abstract}
ABSTRAK
It has been widely recognized that organizational productivity is highly depend on the strategic role of top management team (TMT). The team has critical functions in producing key decisions for sustaining organizational competitive advantage. A numbers of empirical findings also support the fact that the effectiveness of TMT associates with various critical outcomes. Unfortunately, TMT also facing some potential conflict as it consists of various members' diverse backgrounds. How TMT can manage conflict effectively, therefore, has been one of the key success factors in fostering the team effectiveness, which eventually benefits the organizational process. This article exclusively reviews the importance of TMT as a strategic team in organization by evaluating the study of Chen, Liu dan Tjosvold (2005) that investigates how TMTs in Asian context (China) manage conflicts can greatly contribute to their effective leadership of organizational innovation. In discussing team diversity, conflict management and organizational innovation, the article integrates various concepts, empirical findings and methodological issues from the literature.
\end{abstract}

Keywords: top management team, TMT, conflict management, team diversity, organizational innovation

\section{PENDAHULUAN}

Top Managemen Team (TMT) dalam sebuah organisasi memegang peranan yang penting dalam mengelola konflik karena sebagai sebuah tim yang sentral dalam organisasi, TMT terdiri dari beberapa eksekutif yang memiliki perbedaan pandangan ataupun kontribusi terhadap efektifitas tim (Ordaz et al, 2008). Cara penanggulangan konflik yang dipilih oleh TMT akan sangat berpengaruh terhadap hasil konflik yang dicapai, baik konstruktif maupun destruktif. Tulisan ini, akan secara spesifik mengevaluasi sebuah artikel yang ditulis oleh
Chen et al (2005), terkait bagaimana TMT dalam memilih preferensi pengelolaan konflik yang terjadi di dalam organisasi melalui tiga pendekatan yaitu cooperative, competing dan avoiding. Studi ini dinilai menarik karena dapat mengungkap sejumlah isu penting tentang TMT dan manajemen konflik. Resolusi konflik oleh para peneliti ini dikaitkan dengan hasil konflik, efektifitas tim dan inovasi organisasional. Menariknya, penelitian oleh Chen et al (2005) ini dilakukan dalam konteks Asia, khususnya di Cina. Dengan demikian, dapat memberikan gambaran tentang generalisasi studi TMT dan konflik pada konteks yang berbeda. 
Sebagai acuan diskusi, telaah ini akan melakukan tinjauan khusus terhadap studi Chen et al (2005) melalui beberapa tahapan. Setelah pendahuluan, penulis akan memasuki bagian inti selanjutnya dari tinjauan yakni diskusi terhadap beberapa teori dan topik penting yang diangkat oleh peneliti melalui beberapa sub judul. Untuk beberapa persoalan yang diangkat, penulis meminjam pendapat dari beberapa pakar dan penelitian lain diluar artikel ini untuk menunjukkan bahwa beberapa kajian dinilai masih perlu ditingkatkan. Dibagian akhir diskusi ini, juga dianalisa metodologi penelitian yang digunakan oleh Chen, Liu dan Tjosvold (2005), dimana beberapa aspek penelitian dinilai sesuai, akan tetapi beberapa aspek lainnya diyakini membutuhkan perhatian lebih untuk memenuhi kaidah penelitian kuantitatif yang lebih tepat. Pada bagian akhir, penulis akan menutup tinjauan terhadap artikel yang dipilih dalam kesimpulan yang memuat seluruh isi tinjauan ataupun rekomendasi terkait artikel yang diangkat.

\section{REVIEW LITERATUR}

\section{Top Management Team}

Chen et al (2005) mengemukakan bahwa konflik merupakan bagian yang penting dari Top Management Team (TMT), akan tetapi dampaknya akan sangat dipengaruhi oleh bagaimana konflik tersebut dikelola. TMT bergantung kepada pendekatan kooperatif manajemen konflik yang dapat menghasilkan konflik yang produktif dan kemudian menghasilkan keefektifan TMT, yang selanjutnya mendukung inovasi organisasional. Karenanya, studi ini bertolak belakang dengan budaya kolektivisme Cina yang beranggapan bahwa menghindari konflik merupakan cara yang tepat dan bermanfaat. Penelitian ini dilakukan untuk mengungkapkan bagaimana TMT mengelola konflik dapat memberikan kontribusi yang besar terhadap efektifitas kepemimpinan dalam inovasi organisasional.
Karenanya, dilakukan kajian yang melibatkan 378 eksekutif dari 105 organisasi di Cina untuk mengukur manajemen konflik (yang terdiri dari pendekatan cooperative, competitive, dan avoiding) and productive conflict (sebagai hasil dari konflik). Secara terpisah, 105 chief executive officers (CEOs) dari perusahaan ini diteliti terkait efektifitas tim dan inovasi organisasional.

Dalam studi Chen et al (2005) dihipotesiskan bahwa cooperative berhubungan secara positif dengan konflik produktif, sementara competing dan avoiding berhubungan secara negatif dengan konflik produktif. Selanjutnya, konflik produktif tersebut akan berpengaruh positif terhadap keefektifan tim dan selanjutnya berpengaruh positif pada inovasi organisasi. Hasil penelitian mendukung teori yang diangkat bahwa manajemen konflik dapat berkontribusi terhadap team effectiveness dan organizational innovativeness. Dengan menggunakan structural equation analysis, studi ini mengungkapkan bahwa pendekatan kooperatif mendukung konflik produktif dan efektifitas TMT, yang selanjutnya mendukung inovasi organisasional. Hasil ini, bila dibandingkan dengan penelitian sebelumnya, justru memberikan pandangan bahwa manajemen konflik kooperatif merupakan kontributor penting bagi efektifitas TMT termasuk juga dalam konteks budaya kolektivitas di Asia, khususnya Cina.

\section{TMT Sebagai Sebuah Tim Strategis}

TMT adalah tim yang paling berpengaruh di dalam organisasi dalam mengimplementasikan atau menghindari perubahan, selain itu, TMT juga bertanggung jawab membentuk strategi dan memastikan terciptanya efektifitas organisasi (Rapp, Schillewaert dan Hao, 2008). Namun, anggota TMT juga harus membangun mekanisme untuk memastikan perlunya perubahan melalui pembentukan kerjasama tim yang efektif (Camelo-Ordaz, $d k k$., 2008). Kerjasama tim dapat menghasilkan instrumen dasar untuk membantu organisasi menciptakan pengetahuan baru pada 
level kelompok serta penerapan pengetahuan baru tersebut di dalam organisasi, yang selanjutnya dapat meraih kesuksesan inovasi. Dalam studi ini (Chen et al, 2005) berpendapat bahwa berdasarkan penelitian sebelumnya, tidak dijamin TMT memiliki kapabilitas yang diharapkan untuk menuntun, mendukung ataupun menginspirasi tim-tim yang lain dalam berinovasi dan menanggulangi hambatan-hambatan; padahal TMT berada di level yang paling tinggi. Menurut mereka bahwa hal tersebut dapat disebabkan oleh kegagalan dalam menyatukan informasi ataupun ide-ide bagi pengambilan keputusan yang efektif.

Menurut Parker dan Fischhoff (2005), kemampuan mengintegrasikan kepercayan dan nilai-nilai saat membuat keputusan dapat menghasilkan aturan keputusan yang lebih tepat, karenanya dapat dilaksanakan dengan lebih akurat. Aspek yang paling mendasar dari pekerjaan para eksekutif adalah terjalinnya interaksi antara anggota tim, yang sangat dilandasi oleh keterbukaan, kejujuran dan terciptanya dukungan bagi anggota yang lain untuk melakukan hal serupa (Kipp dan Kipp, 2000). Interaksi tim yang terjadi diharapkan dapat menyesuaikan dengan kondisi lingkungan karena keefektifan tim yang sesungguhnya adalah mempertahankan kinerja kolektif tingkat tinggi, meskipun lingkungan tidak mendukung (Zaccaro et al, 2001). Selanjutnya, kinerja yang tinggi membutuhkan tim yang dapat membangun norma-norma dan prosedur operasional yang mensponsori fleksibilitas dan adaptasi kolektif. Sebuah tim yang sukses juga membutuhkan kerjasama dan kolaborasi tingkat tinggi antar anggota dan pimpinan tim (Gillespie dan Mann, 2004). Terkadang, anggota tim justru mempunyai pengetahuan yang lebih maju dibandingkan pimpinan mereka, dan karenanya, tim bergantung kepada anggotanya untuk berbagi ide-ide ilmiah mereka secara terbuka dan memberikan umpan balik yang jujur kepada sesama anggota dalam meciptakan produk maupun proses yang inovatif. Hanya tim-tim yang mampu bekerja secara otonom dan fleksibel yang dapat membangun organisasi yang inovatif (Tranfield dan Smith, 2002). Singkatnya, banyak hal yang harus dilakukan oleh TMT dalam memastikan terjadinya integrasi yang baik antar anggota tim untuk mewujudkan tim yang efektif.

\section{Kerjasama Tim dan Konflik}

Beberapa pakar percaya bahwa sebuah organisasi merupakan refleksi dari kinerja TMT. TMT dianggap sebagai level tertinggi manajemen yang bertanggung jawab mengawasi seluruh organisasi dan secara khusus terlibat dalam berbagai hal strategis dan konseptual, karenanya mempengaruhi kinerja organisasi (Rapp et al, 2008). Hal ini juga sejalan dengan pendapat Eisenhardt et al (1997) karena TMT terdiri dari para eksekutif senior sebagai perwakilan eksternal organisasi dan merupakan panutan bagi karyawan, karenanya, peran mereka sangat penting dalam sebuah tim. Bila kepustakaan lain dikaji, maka secara bersama-sama, TMT tidak hanya membentuk visi perusahaan tetapi juga mengartikulasi dan melaksanakan visi tersebut melalui serangkaian interaksi kelompok yang terjadi secara terus menerus (Eisenhardt et al, 1997). Namun, karena terdiri dari beberapa individu yang berbeda, TMT terdiri dari beragam pandangan dan karakteristik yang berbeda, sehingga diversitas merupakan hal sentral yang mewarnai TMT. Pada kenyataannya, perbedaan merupakan salah satu faktor penyebab terjadinya konflik. Menurut beberapa pakar, perbedaan tidak hanya meningkatkan kualitas pengambilan keputusan dan kreativitas anggota kelompok, tetapi juga dapat menyebabkan konflik, kesalahpahaman dan bahkan turnover (Milliken \& Martins, 1996; Jehn \& Thatcher, 1997; Garcia et al, 2003). Chen et al (2005) dalam studi ini menyebutkan isu diversitas terutama terkait cara berpikir para manajer yang bila dapat dikelola dengan baik dapat menstimulus terciptanya 
inovasi. Namun sayangnya, peneliti tidak mendiskusikan lebih lanjut perbedaan lain yang juga sangat terkait dengan munculnya konflik dalam organisasi umumnya atau TMT khususnya, terutama yang terjadi pada perusahaan Cina yang diteliti.

Menurut Friedman dan Davidson (2001), konflik yang disebabkan oleh perbedaan atau konflik diversitas terjadi karena perbedaan anggota kelompok. Lebih tepat lagi, diversitas merujuk kepada hadirnya perbedaan di dalam unit sosial atau kerja kelompok terkait beberapa sifat demografis (Hobman et al, 2003; You-Ta et al, 2004). Sehingga, mempertimbangkan hadirnya perbedaan demografi merupakan hal yang penting, karena selain untuk penciptaan budaya perusahaan yang kuat dan keseimbangan antara pekerjaan dan sisi lain kehidupan karyawan, unsur demografi juga berguna dalam mengelola konflik (Daft, 2004). Atribut demografi dibedakan menjadi dua kategori. Kategori pertama adalah aspek-aspek yang mudah diamati seperti umur, jenis kelamin dan etnis sementara kategori kedua adalah atribut mendasar seperti pendidikan dan kemampuan teknis (Garcia-Prieto et al 2003). Pada dasarnya, Jehn dan Thatcher (1997) menyebutkan bahwa anggota kelompok yang merasa memiliki kesamaan dengan yang lainnya, maka cenderung untuk menyetujui langkahlangkah yang diambil di dalam kelompok. Sebaliknya, anggota kelompok yang memiliki perbedaan mendasar dapat menimbulkan lebih banyak konflik, turnover yang tinggi, rendahnya kepuasan kerja serta lebih banyak stress, ketidakhadiran dan masalah-masalah komunikasi (Ayoko et al, 2002). Karenanya, mengabaikan unsur-unsur demografi dalam penelitian ini akan sangat berpengaruh terhadap hasil penelitian, terlebih lagi, peneliti tidak menyebutkan faktorfaktor demografi sebagai variabel yang dikontrol. Diyakini, bila perbedaan demografi sangat rendah dalam organisasi yang diteliti, maka kemungkinan terjadinya konflik sangat kecil ataupun bila terjadi konflik, anggota TMT akan cenderung bekerja sama dalam pengambilan keputusan sehingga konflik fungsional lebih mudah diraih.

\section{TMT dan Inovasi}

Dalam artikel ini Chen et al (2005) juga mengemukakan bahwa TMT yang menitikberatkan pada pendekatan kooperatif dalam mengelola konflik dapat menghasilkan konflik yang produktif atau bila meminjam pendapat lain seperti Robbins et al (2001), disebut sebagai konflik yang fungsional. Selanjutnya menurut studi ini, konflik produktif tersebut dapat mendukung organizational innovativeness. Namun, mengingat inovasi organisasional merupakan variabel dependen sebagai akhir dari model penelitian yang dikaji, diskusi mengenai inovasi dinilai dalam studi ini sangat singkat (Chen et al, 2005) dengan hanya menggunakan satu persepsi inovasi menurut West (2002). Padahal, dalam beberapa kajian lain, definisi mengenai inovasi diperdebatkan karena banyak sekali pendekatan yang berbeda mengenai kosep ini dalam literatur. Johannessen et al (2001) misalnya berpendapat bahwa keragaman ketetapan terhadap konsep inovasi menyebabkan pemahaman umum mengenai fenomena tersebut semakin sulit. Bila mengkaji definisi inovasi yang diangkat oleh artikel ini (West, 2002), maka kemungkinan peneliti memahami inovasi sebagai proses, sementara menurut kajian, terdapat tiga dimensi yang mendasari inovasi. Yang pertama, inovasi sebagai hasil (results) yang dapat dilihat dari definisi inovasi oleh Tushman dan Nadler (1986) yang paling dikenal, yakni, inovasi merupakan penciptaan produk atau pelayanan baru untuk unit bisnis tertentu. Selain itu, inovasi menyebabkan timbulnya pengetahuan baru, akses pada pasar baru dan membangkitkan perhatian konsumen terhadap pengembangan produk baru (Gibson dan Birkinshaw, 2004). Kedua, inovasi juga dianggap sebagai proses (process) melalui pembentukan ide-ide baru, prosedur atau hal-hal 
yang secara kualitas berbeda dengan keadaan sebelumny (Robertson, 1967). Berikutnya, inovasi juga dianggap sebagai atribut organisasi (attribute) dimana sifat inovatif (misalnya jumlah produk baru yang diciptakan atau jumlah produk yang diperbaharui) melekat pada organisasi sehingga suatu organisasi disebut sebagai organisasi yang inovatif (Bantel dan Jackson, 1989).

Masih terkait dengan inovasi organisasi, tepat bila Chen et al (2005) menyinggung peran TMT dalam membantu organisasi untuk secara berkesinambungan memperbaharui strategi organisasi dalam merespon pasar dan perubahan teknologi, atau dengan kata lain, mendukung organisasi menjadi inovatif. Sehingga, sangat tepat bila peneliti ini juga sedikit mengungkap tentang kemampuan belajar eksekutif senior dalam menunjang terbentuknya organisasi yang inovatif. Proses inovasi terkait erat dengan proses pembelajaran karena organisasi selalu berusaha dan belajar menciptakan hal-hal baru dan hal ini dapat terjadi bila perangkat organisasi, terutama TMT sebagai tim inti, memiliki kapabilitas belajar individu maupun kelompok yang efektif. Karena organisasi terdiri dari para individu di dalamnya, maka organisasi belajar melalui pengalaman-pengalaman dan tindakan individu (Argyris, 2002). Sehingga, kemampuan belajar para eksekutif sangat berpengaruh terhadap kesuksesan organisasi dalam memperbaharui diri.

Menurut Argyris (2002), terdapat dua cara individu belajar, yakni single-loop learning dimana nilai-nilai dasar yang ada, norma-norma dan mental model masih tetap sama saat seseorang mendeteksi dan memperbaiki kesalahan internal maupun eksternal. Akibatnya, para eksekutif dan manajer terjebak dalam cara mereka berpikir dan melihat dunia dan menganggapnya sebagai satu-satunya realitas (Morgan, 1997). Sebaliknya double-loop learning merupakan program utama dan tujuan dari konsep pembelajaran ketika kesalahan dideteksi dan dikoreksi dengan mengubah asumsi-asumsi dasar yang dimiliki (Argyris, 2002). Dengan mengubah mental model, kapabilitas manajer dalam kegiatan penyelesaian masalah dapat ditingkatkan (Chapman \& Ferfolja, 2001). Sebagai sebuah tim, TMT terdiri dari para senior eksekutif di dalamnya, sehingga efektifitas tim sangat dipengaruhi oleh cara belajar anggota TMT, apakah single-loop learning atau double-loop learning, yang kemudian akan mempengaruhi kapabilitas belajar kelompok (TMT). Lebih luas lagi, kemampuan organisasi untuk berinovasi, sangat dipengaruhi oleh kinerja tim-tim yang ada di dalamnya, terutama bagaimana TMT meningkatkan efektifitas belajar mereka dalam mendukung pembaharuan organisasi (inovasi) secara berkesinambungan.

\section{Manajemen Konflik}

Penanganan konflik adalah sebuah proses dimana komunikasi interpersonal digunakan untuk memperkenankan dua pihak yang bertikai dalam meraih permufakatan (Salami, 2010). Berdasarkan studi Chen et al (2005), para peneliti menguji tiga pendekatan dalam mengelola konflik dari teori cooperation and competition yang terdiri dari cooperative, competing dan avoiding. Namun, dari kajian manajemen konflik, beberapa peneliti lain tidak hanya memiliki tiga preferensi tetapi menggunakan lima pendekatan yang lebih komprehensif, misalnya konsep yang sering dirujuk yakni milik Thomas-Kilmann melalui Dimension of Conflict Handling Intentions (Robbins et al, 2001). Penanganan konflik ini terdiri dari dua dimensi utama yakni cooperativeness (sejauh mana satu pihak berusaha untuk memuaskan kepentingan pihak lain); dan assertiveness (sejauh mana satu pihak berusaha untuk memuaskan kepentingan dirinya sendiri atau pihak lain). Competing (termasuk assertive dan uncooperative), collaborating (termasuk assertive dan cooperative), avoiding 
(termasuk unassertive dan uncooperative), accommodating (termasuk unassertive dan cooperating), dan compromising (berada pada level tengah assertiveness sekaligus cooperatieness). Sementara itu, beberapa pakar lain juga menggunakan lima strategi resolusi konflik yakni confronting/collaborating, withdrawing/avoiding, forcing/competing, smoothing, dan compromising (Meyer, 2004). Disayangkan, Chen et al (2005) tidak secara jelas menyebutkan mengapa hanya memilih tiga dari lima kategori umum penanganan konflik yang biasanya digunakan dalam literatur manajemen konflik.

Tsai dan Chi (2009) meneliti lima cara penanganan konflik seperti yang ditawarkan Thomas-Kilmann Conflict Mode Instrument hanya saja menggunakan istilah dominating untuk menggantikan competing. Peneliti ini dilakukan juga di Cina dengan mengevaluasi budaya Cina melalui dimensi budaya Hofstede (power distance, individualism versus collectivism, femininity versus masculinity, uncertainty avoidance, dan long-term versus short-term orientation) untuk melihat pengaruhnya terhadap pemilihan strategi resolusi konflik pada industry konstruksi. Dari studi tersebut ditemukan bahwa pertama, power distance berhubungan dengan pendekatan dominating dan accommodating; kedua, uncertainty avoidance berkaitan dengan tendensi untuk menggunakan cara accommodating atau avoiding; ketiga, collectivism ternyata ditemukan berhubungan dengan collaborating dan accommodating. Keempat, studi Tsai dan Chi (2009) membuktikan bahwa masculinity berkaitan dengan dominating dan collaborating sementara femininity terkait dengan avoiding dan accommodating. Dan kelima, long-term orientation meningkatkan preferensi compromising sementara short-term orientation memotivasi penggunaan penyesuaian dari beberapa cara menghadapi perubahan situasi yag terjadi. Dari penelitian Tsai dan Chi
(2009) ini terlihat bahwa dalam budaya Cina sendiri, dimensi budaya yang berbeda dapat juga menghasilkan cara penanganan konflik yang beragam, tidak hanya kecenderungan pada pendekatan cooperative atau avoiding sebagaimana yang didiskusikan dalam artikel Chen et al (2005). Perlu diketahui babhwa Cina saat ini sedang mengalami transformasi menjadi lebih terbuka, modern dan market-oriented society (Tjosvold et al, 2001). Karenanya, para manajer Cina menghadapi lebih banyak konflik dan tantangan dalam mereformasi ekonomi dan bekerjasama dengan beberapa Negara seperti Jepang, Amerika, negara-negara Asia Tenggara, Eropa dan hubungan internasional lainnya (Tjosvold, 2000).

\section{ISU-ISU METODOLOGIS}

Chen et al (2005) dalam studi mereka menggunakan sampel sejumlah 105 TMT yang terdiri dari 105 CEOs dan 378 executives sehingga dinilai sudah memenuhi syarat dengan menggunakan analisis SEM. Menurut Hair et al (2010), SEM membutuhkan sampel yang relatif besar dibandingkan pendekatan yang lain. Dengan mempertimbangkan multivariate normality maka dibutuhkan 15 responden untuk setiap parameter dalam model Structural Equation Model (SEM) yang digunakan. Jika demikian, maka penelitian Chen et al (2005) ini memiliki 30 parameter (dari 6 konstruk yang diukur) sehingga sampel minimum haruslah sebesar 450. Dalam penelitian ini seluruh sampel (CEOs dan senior executives) berjumlah 483 , sehingga total sampel diyakini sudah sesuai.

Seperti yang telah dibicarakan sebelumnya, peneliti tidak memperhatikan variabel demografi dalam studi ini. Namun, beberapa penelitian sebelumnya walaupun tidak secara khusus difokuskan pada variabel demografi, memasukan unsur-unsur demografi sebagai variabel kontrol. Karena dalam sebuah tim, beberapa aspek dari komposisi demografi 
dapat mempengaruhi proses dan hasil kerja kelompok (misalnya dilihat pada Barsade et al, 2000). Sayangnya, dari tabel korelasi statistik yang ditampilkan dalam studi Chen et al (2005) ini tidak terlihat adanya indikasi variabel demografi diintegrasikan dalam pengujian model penelitian.

Terkait isu pengukuran, dari 5 konstruk yang diukur, Chen et al (2005) melampirkan instrumen yang digunakan sehingga dapat dianalisa apakah termasuk indikator reflektif atau formatif. Menurut MacKenzie et al (2005), kesalahan dalam membedakan formative dan reflective indicators dapat mempengaruhi statistical conclusion validity dari hasil penelitian. Selain itu, misspecification juga mengakibatkan Type I dan/atau Type II Error pada pengujian hipotesis. Selain itu menurut Hair et al. (2010), indikator formatif bukan termasuk latent (tidak dapat diobservasi) dan tidak divalidasi sebagaimana indikator reflektif, karenanya, menggunakan indikator formatif menyebabkan kesulitan yang cukup besar dalam identifikasi statistik. Sehingga, dalam menguji model SEM, indikator reflektif termasuk yang paling tepat digunakan. Dalam penelitian Chen et al (2010), khususnya pada item-item yang digunakan untuk menguji konstruk "team effectiveness" dapat dikatakan bahwa beberapa item tergolong sebagai indikator formatif karena bukan merupakan hasil (outcome) dari "team effectiveness" melainkan faktor pembentuk konstruk tersebut. Misalnya pada item "team members work effectively" atau "team members put considerably effort into their jobs" dan "team member are concerned about the quality of their work". Kesalahan dalam mencampurkan kedua jenis indikator ini akan berakibat fatal terhadap pengujian hipotesis. Selebihnya, item-item pada konstruk ini sudah mencerminkan refleksi atau effect dari "team effectiveness" sebagaimana yang dikemukakan oleh Robbins et al. (2001) bahwa efektifitas tim dapat dilihat dari beberapa aspek. Pertama, keluaran yang diproduksi oleh tim (misalnya dilihat dari kuantitas, kualitas, kecepatan); kedua, konsekuensi tim pada anggotanya (kepuasan, komitmen dan kepercayaan); dan yang ketiga adalah pengingkatan kemampuan anggota tim untuk bekerja lebih efektif dimasa depan.

Kembali ke persoalan formatif dan reflektis, kesalahan interpretasi indikator penelitian apakah termasuk formatif atau reflektif sering terjadi dalam penelitian (Hair et al, 2010) dan kesalahan tersebut bisa menjadi fatal karena berpengaruh terhadap ditolaknya hipotesis nol yang seharusnya benar (Type I error) atau diterimanya hipotesis nol yang seharusnya salah (Type II error) (MacKenzie, 2005).

Untuk pengujian hipotesis, peneliti menggunakan alat analisis SEM yang dinilai sangat tepat karena menurut Hair et al. (2010) SEM sesuai digunakan untuk menguji struktur hubungan secara simultan dalam model hipotesa dan memungkinkan pengujian sejauh mana model tersebut konsisten dengan data. Karena menggunakan SEM, peneliti juga melakukan pengujian selain pada model yang dihipotesiskan, juga terhadap alternatif model 1, 2 dan 3 (Chen et al, 2005). Namun dari hasil pengujian ditemukan bahwa model yang dihipotesiskan adalah yang paling baik ditandai dengan Chi-Square $\left(X^{2}\right)$ yang paling rendah yakni 20,26, sedangkan model 1, 2, dan 3 masing-masing memiliki $X^{2}$ 131.65, 93.22 dan 50.65. Menurut Hair et al. (2010), dalam pengujian model menggunakan SEM, Chi-Square $\left(X^{2}\right)$ minimum yang dicari karena mengindikasikan bahwa model penelitian tidak memiliki perbedaan yang berarti dari kenyataan sesungguhnya. Selain itu, Comparative Fit Index (CFI) untuk model yang dihipotesiskan juga ditemukan paling mendekati 1 yakni 0.95; karena semakin tinggi nilai CFI, semakin tepat (fit) model yang diteliti, dan biasanya nilai CFI di atas 0.90 diasosiasikan sebagai model yang tepat (Hair et al, 2010). 


\section{KESIMPULAN DAN SARAN}

Sejumlah isu telah mengemuka khususnya terkait TMT dan faktor-faktor penting terkait. Khususnya, telaah mendalam terhadap studi Chen et al (2005) mengungkapkan beberapa aspek yang perlu dikaji kembali untuk memperdalam kajian tentang TMT, terutama terkait konsep konflik dalam tim, inovasi organisasi dan cara penanggulangan konflik yang dilakukan oleh TMT. Misalnya, kajian terhadap variabel inovasi sebagai dependent variable dari model SEM yang diuji, dinilai masih kurang komprehensif dengan hanya diangkatnya pengertian inovasi dari satu sudut pandang saja, sementara dalam literatur ditemukan bahwa memahami persoalan inovasi membutuhkan perdebatan yang panjang oleh para pakar sebelumnya. Selain itu, tulisan ini juga diantaranya mengomentari pendapat peneliti bahwa budaya Cina, dalam perusahaan yang diteliti, memiliki kecenderungan untuk memilih resolusi cooperative atau avoiding. Dari penelitian lain (Tsai et al, 2005) ditemukan bahwa kecenderungan pemilihan cara penanggulangan konflik tidak terbatas pada tiga aspek yang dikaji dalam penelitian Chen et al (2005); karena ternyata dari hasil penelitian Tsai et al. (2005) ditemukan bahwa TMT di Cina memiliki preferensi untuk menggunakan variasi lima jenis resolusi konflik tergantung kepada dimensi budaya Hofstede yang dimiliki oleh perusahaan yang diteliti.

Selain itu, terkait metodologi penelitian, beberapa faktor dianggap telah memenuhi syarat pengukuran model dengan menggunakan SEM misalnya ukuran sampel yang sudah dinilai tepat. Namun demikian, ada beberapa faktor yang diyakini seharusnya dimasukkan dalam desain penelitian misalnya pertimbangan akan adanya beberapa variabel kontrol yang berasal dari perbedaan demografi. Hal ini penting karena beberapa faktor demografi dari penelitian sebelumnya terbukti berpengaruh terhadap hasil penyelesaian konflik. Selain itu, terdapat persoalan penting untuk dipertimbangkan oleh peneliti (Chen et al, 2005) misalnya kemampuan untuk mengidentifikasi indikator formatif maupun reflektif dari instrument pengukuran konstruk "team effectiveness". Bila dianalisa lebih lanjut, ditemukan dari satu konstruk tersebut beberapa item merupakan formatif dan selebihnya adalah reflektif, sementara menurut MacKenzie et al. (2005), kesalahan dalam mengidentifikasi kedua jenis indikator atau menggabungkannya ke dalam satu konstruk dapat berpengaruh terhadap Type I dan Type II error dalam pengujian hipotesis.

\section{DAFTAR PUSTAKA}

Argyris, C. (2002), "Double-Loop Learning, Teaching and Research", Academy of Management Learning and Education, Vol. 1, pp. 206-218.

Ayoko, O. B., Hartel, C.E.J. dan Callan, V.J. (2002), "Resolving the Puzzle of Productive and Destructive Conflict in Culturally Heterogeneos Workgroups:

A Communication Accommodation Theory Approach", The International Journal of Conflict Management, Vol. 13, No. 2, pp. 165-195.

Bantel, K., dan Jackson, S. (1989), “Top Management Innovation in Banking: Does The Composition of the Top Team Make a Difference?", Strategic Management Journal, 10, 107-124.

Barsade, S.G., Ward, A.J., Turner, J.D.R. dan Sonnenfeld, J. A. (2000), "To Your Heart's Content: A Model of Affective Diversity in Top Management Teams", Administrative Science Quarterly, 45, pp. 802-836.

Camelo-Ordaz, C., Fernandez-Alles, M.N. dan Valle-Cabrera, R. (2008), "Top Management Team's Vision and Human Resources Management Practices 
in Innovative Spanish Companies", The International Journal of Human Resource Management, Vol. 19, No. 4, pp. 620-638.

Chen, G., Liu, C. dan Tjosvold, D. (2005), "Conflict Management for Effective Top Management Teams and Innovation in China", Journal of Management Studies 42:2, pp. 278-300.

Daft, R. L. (2004), Organization Theory and Design, (8th edn) South Western Thompson, Ohio.

Eisenhardt, K. M., Kahwajy, J. L. dan Bourgeois III, L. J. (1997), "Conflict and Strategic Choice: How Top Management Teams Disagree", California Management Review, Vol. 39, No. 2, pp. 42-62.

Friedman, R. A. dan Davidson, M. N. (2001), "Managing Diversity and Second Order Conflict", The International Journal of Conflict Management, Vol. 12, No. 2, pp. 132-153.

Garcia-Prieto, P., Bellard, E. dan Schneider, S. C. (2003), "Experiencing Diversity, Conflict and Emotions in Teams", Applied Psychology: an International Review, Vol 52, No. 3, pp. 413-440.

Gillespie, N. A. dan Mann, L. (2004), "Transformational Leadership and Shared Values: The Building Blocks Of Trust" Journal of Managerial Psychology, Vol. 19 No. 6, pp. 189-197.

Hair, J.F., Black, W.C., Babin, B.J. dan Anderson, R.E. (2010), Multivariate Data Analysis: a Global Perspecive, $7^{\text {th }}$ Eds. Pearson, USA.

Hobman, E. V., Bordia, P. dan Gallois, C. (2003), "Consequences of Feeling Dissimilar from Others in a Work Team", Journal of Business and Psychology, Vo. 17, No. 3, pp. 301-322.

Jehn, K. A. dan Thatcher, S. M. B. (1997), “To Agree or not to Agree: the Effects of Value Congruence, Individual
Demographic Dissimilarity, and Conflict on Workgroup Outcomes", The International Journal of Conflict Management, Vol. 8, No. 4, pp. 287-305. Johannessen, J.A., Olsen, B., dan Lumpkin, G.T. (2001), "Innovation as Newness: What is New, How New, and New to Whom?," European Journal of Innovation Management, 4:1, 20-30.

Kipp, M. F. dan Kipp, M. A. (2000), "Of Teams and Teambuilding", Team Performance Management: An International Journal, Vol. 6. No. 7/8, pp. 138-149.

MacKenzie, S. B., Podsakoff, P. M. dan Jarvis, C. B. (2005), "The Problem of Measurement Model Misspecification in Behavioral and Organizational research and Some Recommended Solutions", Journal of Applied Psychology, Vol. 90, No. 4, pp. 710-730.

Miliken, F. J. dan Martins, L. L. (1996), "Searching for Common Threads: Understanding the Multiple Effects of Diversity in Organizational Groups", Academy Management Review, Vol. 21. No. 2, pp. 402-434.

Morgan, G. (1997), Images of Organization, Sage Publications, California.

Parker, A. M. dan Fischhoff, B. (2005), “DecisionMaking Competence: External Validation through an IndividualDifferences Approach", Journal of Behavioral Decision Making, 18: 1-27.

Rapp, A, Schillewaert, N. dan Hao, A. W. (2008), "The Influence of Market Orientation on E-Business Innovation and Performance: The Role of The Top Management Team", Journal of Marketing Theory and Practice, Vol. 16, No. 1, pp. 7-2.

Robertson, T.S. (1967), "The Process of Innovation and the Diffusion of Innovation," Journal of Marketing, 31, 14-19. 
Robbins, S. P., Millet, B., Cacioppe, R. \& WatersMarsh. T. (2001), Organizational Behavior, 3rd Ed., Prentice-Hall, Australia.

Salami, S. O. (2010), "Conflict Resolution Strategies and Organizational Citizenship Behavior: The Moderating Role of Trait Emotional Intelligence" Social Behavior and Personality, 38(1), $75-86$.

Tjosvold, D. (2000), "An Encounter with a Face of Chinese Capitalism", Journal of Management Inquiry, 87, pp. 87-91.

Tjosvold, D., Hui, C. dan Law, K. S. (2001), "Constructive Conflict in China: Cooperative Conflict as a Bridge between East and West", Journal of World Business, 36: 2, pp. 166-183.
Tranfield, D. dan Smith, S. (2002), “Organisation Designs for Teamworking", International Journal of Operations \& Production Management, Vol. 22 No. 5, 2002, pp. 471-491.

Tsai, J. S. dan Chi, C. S. F. (2009), "Influences of Chinese Cultural Orientations and Conflict Management Styles on Construction Dispute Resolving Strategies", Journal of Construction Engineering and Management, Vol. 135, No. 10, pp. 955-964.

Tushman, T., dan Nadler, D. (1986), “Organizing for Innovation", California Management Review, 28, 3, 74-92.

Zaccaro, S.J., Rittman, A. L. dan Marks, M. A. (2001), "Team leadership", The Leadership Quarterly, 12, pp. 451-483. 